研究課題別評価

1 研究課題名：蛋白質1個における局所的構造変化の可視化

2 研究者氏名：西坂崇之

3 研究のねらい:

近年の顕微鏡技術の発展により、従来はマクロな分子の集団において研究されていた試料 が、個々の分子を対象とし、その個性や不均一性が議論され始めた. これら1分子研究の流れ を受け、本課題では、 1 個の生体分子の中で起きる構造変化や化学反応を、顕微鏡下で直接 可視化することを目的とした. 本研究者によって考案された顕微鏡 (特許取得済) は、独自の光 学系によって全反射照明を実現しており、ガラス基板近傍の色素 1 分子の角度変化を〜 $5^{\circ}$ の 精度で検出することができる. この顕微鏡を実際に開発し、ダイナミックな構造変化を行う蛋白 質に応用することで、蛋白質 1 分子の中の構造変化、さらには特定のサイトで起きる化学反応 を定量的に明らかにする. 最終的には、蛋白質の動作メカニズムに、1分子のレベルで踏み込 む. この新しい手法は、様々な蛋白質を対象に応用され発展するというポテンシャルを持つ.

4 研究成果:

ガラス面に吸着したタンパク質を高感度の蛍光顕微鏡で観察し、その情報を1分子のレベルで 取り出す新しい実験系の構築を行った.この実験系を用い、回転分子モーターである $\mathrm{F}_{1}$-ATPaseが、エネルギー源であるATPを取り込みながらステップ状に回転する様子を画像化 することに成功した. またタンパク質の局所的な構造や、粒子の3次元的な動きを高速で検出す るという、独自の光学顕微鏡の開発にも成功した.

\title{
(1) 新しい顕微鏡技術
}

蛋白質の活性を定量的に調べる場合、分光学的手法が主流であり、活性の指標となる分解産 物に反応して光の吸収もしくは蛍光が変化するプローブが用いられる. この時、測定の対象とさ れる蛋白質は約 $10^{12} 、$ 一兆個にも達する. 同じ光を用いるのであれば、分光器よりはるかに感 度と空間分解の高い技術が存在する. それが光学顕微鏡である. カメラやフィルター、光学系 の急速な技術の発展により、水の中の 1 個の蛍光色素を検出することが可能となっている. 本 研究では、1分子を観察する技術の中で、全反射型蛍光顕微鏡 (total internal reflection fluorescent microscope, TIRF)に注目して顕微鏡技術の開発を行った. TIRFとは、色素の励起 に用いるレ一ザー光をガラスと水の界面で全反射させ、ガラス近傍に発生するエバネッセント場 により試料を観察する手法である. エバネッセント場は深さ〜 100 ナノメートルで消光し水中に侵 入しないので、水中に色素がある場合でも、通常の方法に比べ格段に背景光を抑えることがで きる.

研究者が開発した光学系では、エバネッセント場の偏光を $x y$ 方向に時間的に変化させること ができる. 蛍光色素は、色素固有の特定の波長によって励起されて光を放出するが、その励起 効率は、色素の振動モ一メントの向きに依存する. 色素の向きと励起光の偏光がー致している 場合には信号は最大となり、直行する場合は最小となる. 図の光学系では、エバネッセント場の 偏光が時間と共に回転するようになっている(関連特許:3577514号、発明の名称「全反射型 蛍光顕微鏡」、発明者 西坂崇之).この光学系で1分子の蛍光色素を観察すると、色素はその 向きを反映して明滅を行うことになる.

（2）1分子の反応の画像化

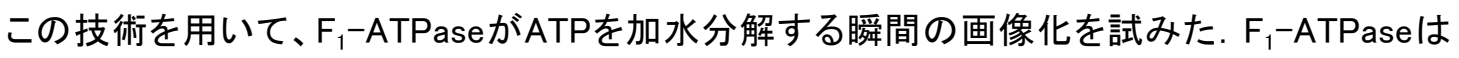
ATP合成酵素の 1 部分であり、 $\alpha_{3} \beta_{3} \gamma \delta \varepsilon$ のサブュニット構成になっている.' 97 年にATPを分解し ながら一方向に回転する分子モ一ターであることが分かり、本研究では回転の最小単位である $\alpha_{3} \beta_{3} \gamma$ を用いている. 
観察系では、基質であるATPを蛍光色素Cy3 で標識し、ガラス面上に固定した 1 分子の $F_{1}$-ATPaseとATPが結合·解離する様子を高感度カメラで撮影した. $F_{1}$-ATPaseにはATPを結合 する触媒部位が3力所あるので、複数個のATP/ADPから1回の反応を分離する必要があり、溶 液には無標識のATPを混在させている. モ一ターの回転軸である $\gamma$ の回転はポリスチレン微小 球(ビーズ)によって検出する(論文 (3)).

この測定で特徵的なのは、独自の顕微鏡によってエバネッセント波の偏光が試料の $\mathrm{xy}$ 平面 内において一定速度で回転しているという点である. 結合後の Cy3-ATP1分子の強度を見ると、 偏光の回転に応じて強度が明滅しており、ここから Cy3-ATP の色素の角度が決定できる. 同じ 分子を対象にして複数の Cy3-ATP によるステップを調べたところ、 $\gamma$ の角度とATP の方向には 明らかな相関があることが分かった. すなわち3つある触媒サイトのうち、どこに ATP が結合し たのかを区別することができ、しかも回転軸 $\gamma$ の向きはその触媒サイトによって決定されること が明らかになったのである

\section{(3) $F_{1}$-ATPaseの回転メカニズム}

本研究で用いた変異体タンパク質 (文献 (4))では、無標識のATPでは $1 / 3$ 回転 $\left(120^{\circ}\right.$ )のステ

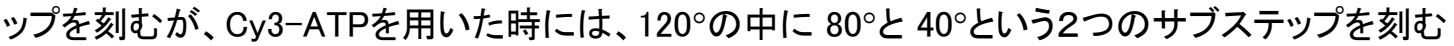
という性質がある. この特徵を指標にして回転の解析を詳細に行った結果、中間状態まで含め た $\mathrm{F}_{1}$-ATPaseの回転スキームが完成された(論文 (1), (5)). ATPが結合して全ての反応が終了 する度に、 $\gamma$ 軸は $120^{\circ}$ ステップを行い完了し、再びATP結合待ちの状態に戻る. 中間状態に関 する重要な結論として、「40॰サブステップは、(いまATPを結合したサイトから見て)1つ前のサイ トにおける反応が支配している」ことが導かれた。

\section{（4） 1 分子の構造変化へ}

以上の研究を通じて $F_{1}-A T P a s e の$ 回転における化学状態が詳細に明らかになったが、ATP加 水分解反応に伴う駆動機構そのものは未だ明らかになっていない. 近年解かれたいくつかの結 晶構造から、触媒サブュニット $\beta$ が複数のコンフォメーションを取りうることが予想されている. そこで偏光の向きが回転する全反射型顕微鏡を用い、回転中の $\beta$ サブュニットの構造変化の 検出を試みた.

3つある $\beta$ 触媒サブュニットのうち、1つの $\beta$ のC末端ドメインにのみに蛍光分子を標識し たところ、Cy3-ATP の実験と同様に色素が明滅する様子が観察された. $\beta$ サブユニットが $120^{\circ}$ おきの3箇所に滞在する時において、この信号を解析したところ、信号の位相が優位に変 化することが分かった. このことから、 $\beta$ の構造変化の検出に成功したといえる. 具体的な角度 変化の詳細については、取得したデータの完全な評価が完全に終わっておらず現在も解析中 であるが、たつた1つの分子に注目しながら、順々に起こる構造変化のひとつだけを見分ける事 が可能になっている. これからは、活性を持った生きた酵素の局所的な構造変化について、結 晶構造と照らし合わせて議論することが可能になっていくだろう. 今後はさらに高速化を目指し た測定に発展させる予定である(特許 (1)).

（5）2次元から3次元へ

従来の顕微鏡観察では、試料の運動について二次元の情報しか含まれず、垂直方向の位置を 正確に知ることはできなかった. そこで微粒子の変位をナノメートルオーダーで三次元的に検出 する新しい光学顕微鏡、TdTIP (three-dimensional tracking by an insertion of prism) Microscope を開発した(特許 (2), (4)). この光学顕微鏡で捉えた蛍光単粒子の像は、プリズム によって二つに分けられており、それぞれの像の平行移動量から水平方向の変位、相対移動 量から垂直方向の変位が、独立かつ同時に検出できるという特徵を持つ. 蛍光微粒子もしくは 1個の蛍光色素による標識によってあらゆる蛋白質に応用できるため、今後、一分子生理学へ の大きな貢献が期待される. 現在、この手法を独自の暗視野顕微鏡(特許 (3)) と組み合わせ、 分子モ一タ一の立体的な動きを定量的に検出するための実験系を構築しようとしている. 
5 自己評価:

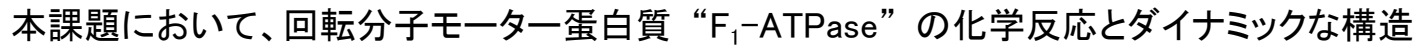
変化が、その中間状態まで含めて 1 分子のレベルで明らかになった. 特に基質の分解と力学反 応が同時に観察された例はアクトミオシン系に続く2例目であり、蛋白質科学全般への強いイン パクトがあったと考えている. 課題申請時に想定していた、ドメインの構造変化を3次元でとらえ る研究については、装置系の開発が十分に進まず期待した成果は得られなかった. しかし2次 元の構造変化については、結晶構造と比較して議論できるだけの優位なデータが出始めており、 課題終了後すぐに成果を論文として発表する予定である. 次の新しい研究へと続く十分な足が かりは得られたと考えている.

また申請当初は想定していなかった、粒子の動きを3次元的に検出する新しい顕微鏡が開 発された.これは予期せぬ成果であり、顕微鏡開発を行っている研究者や技術者からも高い評 価を得ている. 確かな応用へと研究の方向性を定め、新しいサイエンスへ発展させていきたい.

\section{6 研究総括の見解:}

色素で標識したたんぱく質1分子の動きを、色素の角度を3次元的に検出するという発想で 新しい全反射顕微鏡技術を開発し、当初目標に掲げた回転分子モーターたんぱく質の構造変 化を1分子レベルで検出することに成功した点は評価できる。ただ関心が主に技術に向かって いるのか、折角の観測を出発点に鋭く対象に迫ると言う発想に少し甘さがあったのではないか。

発想が非常にユニークで研究者として成長が楽しみである。副産物として非常に簡易な装置 で3次元位置観測ができる光学顕微鏡を開発し、特許出願に結びつけた点もこの研究者ならで はという気がする。

\section{7 主な論文等:}

論文等 5 件

(1) Nishizaka, T., Oiwa, K., Noji, H., Kimura, S., Muneyuki, E., Yoshida, M. and Kinosita, K., Jr.

"Chemomechanical coupling in $\mathrm{F}_{1}$-ATPase revealed by simultaneous observation of nucleotide kinetics and rotation." Nature Structural and Molecular Biology 11, 142-148 (2004)

(2) Yoshida, Y., Shimozawa, T., Nishizaka, T., Ishiwata, S. and Takeuchi, S. "Muscle proteins as high speed nano transporters on micro patterns." MEMS 2006, 134-137 (2006)

(3) Nishizaka, T., Mizutani, K. and Masaike, T. "Single-molecule observation of rotation of $\mathrm{F}_{1}$-ATPase through micro beads." Methods in Molecular Biology, in press.

(4) Muneyuki, E., Watanabe-Nakayama, T., Suzuki, T., Yoshida, M., Nishizaka, T. and Noji, H. "Single Molecule Energetics of $F_{1}$-ATPase motor." Biophysical Journal, in press.

（5）西坂崇之、政池知子「 $F_{1}-A T P a s e$ 化学一カ学カップリング: 1分子の反応を顕微鏡でとら える」生物物理, in press.

特許 国内 3 件、海外 1 件、海外出願申請中 1 件

(1) 特願 2005-101764

発明の名称:「高時間分解能画像化方法及び装置並びに全反射型蛍光顕微鏡」

発明者:西坂崇之 出願人:独立行政法人科学技術振興機構

出願日: 平成 17 年3月 31 日特許出願

(2) 特願 2005-197049

発明の名称:「3次元位置観測方法及び装置」

発明者:西坂崇之 $(80 \%)$ 、水谷佳奈 $(20 \%)$

出願人: 独立行政法人科学技術振興機構 $(80 \%)$ 、学校法人学習院 $(20 \%)$

出願日: 平成 17 年7月6日特許出願

（3）特願 2006-144050

発明の名称:「暗視野顕微鏡およびその調整方法」 
発明者:西坂崇之 $(75 \%)$ 、安田涼平 $(25 \%)$

出願人: 独立行政法人科学技術振興機構 $(62.5 \%)$ 、学校法人学習院 $(37.5 \%)$

出願日: 平成 18 年5月 24 日特許出願

(4) PCT 出願

出願番号:PCT/JP2006/312958

特許の名称: 「3次元位置観測方法及び装置」

発明者: 西坂崇之 $(80 \%)$ 、水谷佳奈 $(20 \%)$

出願人: 独立行政法人科学技術振興機構 $(80 \%)$ 、学校法人学習院 $(20 \%)$

（5） PCT 出願申請中 1 件 